\title{
The effects of pay satisfaction and affective commitment on turnover intention
}

\author{
A'yuninnisa, Rizqi N. $\$ \\ Faculty of Psychology and Neuroscience, Maastricht University, the Netherlands \\ Faculty of Psychology, Universitas Gadjah Mada, Indonesia (rizqi.ayuninnisa@gmail.com) \\ Saptoto, Ridwan \\ Faculty of Psychology, Universitas Gadjah Mada, Indonesia (ridwan_psychology@ugm.ac.id)
}

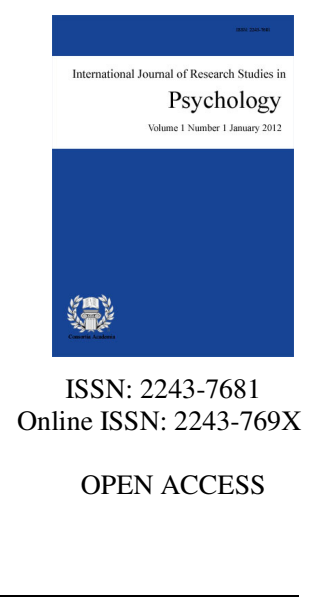

\section{Abstract}

One of the antecedents of turnover and turnover intention is job attitude. Among the job attitudes in the organizations, many researchers have focused on satisfaction and organizational commitment as the factors affecting turnover intention. Meta-analysis studies have noted that correlation between turnover intention and commitment is higher relative to its relationship with satisfaction which indicates the possibility of mediation relationship. One facet of satisfaction which is important in predicting turnover intention is pay satisfaction. Only a few studies have been conducted to test the mediation relationship among the variables. This study aimed to examine the direct and indirect effects of pay satisfaction on turnover intention, which is mediated by affective commitment. Instruments used in this study were the Indonesian version of Pay Satisfaction Questionnaire (Heneman \& Schwab, 1985), Affective Commitment Scale (Allen \& Meyer, 1990), and Turnover Intention Scale, which were delivered to 183 employees of an automotive manufacture company in Indonesia. The data of 150 respondents involved were analyzed using path analysis with latent variables. The result showed that turnover intention was significantly predicted by both pay satisfaction $\left(\gamma_{1}=-.19\right.$, $p<.05)$ and affective commitment $(\beta=-.77, p<.05)$, while affective commitment was significantly predicted by pay satisfaction $\left(\gamma_{2}=.32, p<.05\right)$. The model supported for a partial mediation and that there were both direct and indirect effects of pay satisfaction on turnover. Affective commitment played an effective role in mediating the relationship between pay satisfaction and turnover intention.

Keywords: turnover intention; pay satisfaction; affective commitment; direct effect; indirect effect 


\section{The effects of pay satisfaction and affective commitment on turnover intention}

\section{Introduction}

In recent decades, turnover has become a trend in industrial and organization field. In fact, turnover can give negative impacts to the organization. The cost effect is the main problem turnover brings. Organization should spend a lot of money in separation process and replacement (Kreitner \& Kinicki, 2010). Some studies showed that in every $10 \%$ increasing of turnover rate would cause decreasing of organization outcome (Dolton \& Newson, 2003; Park \& Shaw, 2013). It causes organizations to consume more energy in maintaining the stability of the organization input and output (Shaw, 2011). If the occurrence of this the turnover, particularly the voluntary one, is not controlled, the organization will lose its assets and much cost (Pinder, 2008).

Many studies on turnover have been conducted by investigating the turnover and some job related attitude which antecede its occurrence such as turnover intention, withdrawal cognition, commitment, and satisfaction. A meta-analysis study conducted by Tett and Meyer (1993) investigated the relationships of job satisfaction, organizational commitment, turnover intention, and turnover using path analysis based on the meta-analysis finding. They found satisfaction and commitment as the antecedents of turnover, turnover intention, and withdrawal cognition. However, how much each variable contributed to turnover process limited to the intention/cognition or actual behavior. Satisfaction correlated more strongly than commitment did with intention/cognition. In relation to turnover behavior, satisfaction did correlate less strongly than commitment. It has been noted that turnover intention and cognition were better predictors of turnover than the other attitudinal variables.

A confirmation finding was found by another meta-analysis study conducted by Griffeth, Hom, and Gaertner (2000). More comprehensively, they investigated some factors such as personal characteristics, satisfaction, other dimensions of work experience, external environment factors, behavior predictors, cognition and behaviors of withdrawal process. Based on their findings, turnover was predicted more strongly by commitment than job satisfaction. In addition, they also confirmed that quit intention (i.e., turnover intention) was the best predictor of turnover. By separating the turnover behavior and turnover-related attitude such as turnover intention, this study gave a confirmation to the finding of the previous meta-analysis study. As it suggested commitment as a stronger predictor of turnover than satisfaction, there was a probability of mediation analysis among the variables.

Although many studies have been conducted to see the relationship of satisfaction or any kind of satisfaction (i.e., pay satisfaction), commitment, and turnover intention, there were just few studies conducted intentionally to test the meditation relationship among the variables. Lum et al. (1998) conducted a study investigating nursing turnover and examining the meditation analysis of pay satisfaction, job satisfaction, commitment, and turnover intention. They found that turnover intention was directly predicted by commitment and indirectly predicted by job satisfaction. Pay satisfaction had direct and indirect effects on turnover intention via job satisfaction and commitment.

Another study testing a mediation was relationship conducted by Vandenberghe and Tremblay (2008) which focused more on the effects of pay satisfaction on commitment and turnover intention. Using two samples of subjects, they emphasized the multidimensionality of pay satisfaction (i.e., pay level, raise, structure and administration, and benefits) and organizational commitment constructs (i.e., affective commitment, normative commitment, perceived sacrifice, and perceived lack of alternatives). They found that pay satisfaction could directly and indirectly affect turnover intention. Although all of the components of commitment showed negative correlation with turnover intention, only affective commitment and perceived sacrifice which were found to fully mediate the relationship of pay satisfaction and turnover intention.

Aside from the previous findings on turnover and its antecedents as well as the mediation analysis of 
The effects of pay satisfaction and affective commitment on turnover intention

satisfaction, pay satisfaction, commitment, and turnover intention, this study bases its approach on an actual case of turnover in an automotive manufacture company in Indonesia which was presumably because of pay issue. Thus, this study aimed to examine the direct and indirect effects of pay satisfaction and commitment on turnover intention. This study also recognized the multidimensionality of pay satisfaction as Vandenberghe and Tremblay (2008) did base on practical impact. However, as this previous study did not find satisfactory findings about the role of commitment components as the mediators in the relationship between pay satisfaction and turnover intention, this present study only focused on affective commitment. In addition, the turnover intention measure in this study developed by combining the concept of intention by Ajzen (1991) and turnover intention by (Mobley, Griffeth, Hand, \& Meglino, 1979) in order to better predict the actual turnover.

\subsection{Turnover Intention and Pay Satisfaction}

One critical thing which can explain the linkage between the attitude to turnover and the actual turnover is turnover intention (Steers \& Porter, 1983). Tett and Meyer (1993) suggested turnover intention as a conscious and deliberate willfulness to leave the organization, which is often measured with reference to a specific interval (e.g. within 6 months), and has been described as the last in sequence of withdrawal cognitions. It involves intention to search alternative employment and intention to leave the organization (Mobley et al., 1979). This intention is possible to be translated into behavior in an appropriate time and opportunity. Turnover intention is believed to be the best predictor of actual turnover (Cho \& Lewis, 2012; Griffeth et al., 2000; Podsakoff, LePine, \& LePine, 2007).

As the last in sequence of withdrawal cognition, turnover intention is predicted by satisfaction (Tett \& Meyer, 1993). One facet of employee satisfaction which is crucial for ones well-being and sufficient to influence one's behavior is satisfaction toward compensation or pay. Considered as a tangible symbol of working exchange and relationship between employer and employee, compensation should be equally distributed (Milkovich \& Newman, 2005). If the employees do think that there is a discrepancy between how much pay they should receive and how much pay they do receive, they will experience pay dissatisfaction (Lawler, 1971; Locke, 1969).

Since the beginning of the concept about pay satisfaction developed, there have been some arguments and studies improving this concept until a concept of its dimensions emerged. Lawler (1971) argued that one thing which is considered in evaluating pay is pay level. He believes that pay level is a dimension of pay satisfaction. Later, Dyer and Theriault (1976) tried to examine the model of pay satisfaction proposed by Lawler and found that besides pay level, there was another predictor of pay satisfaction, namely the pay system administration. Those two dimensions together affect pay satisfaction. Heneman and Schwab (1985) completed those dimensions of pay satisfaction with the other two dimensions, benefits and pay raise.

Finally, scientists have agreed that pay satisfaction is multidimensional (Heneman \& Schwab, 1985; Scarpello, Huber, \& Vandenberg, 1988). They proposed that pay satisfaction comprised four dimensions. Pay level refers to individual's current direct compensation (wage or salary), which is set by the organization. Pay raise is the individual's changes in pay level as being set by organization and based on job classification or other criteria. Structure/administration refers to the hierarchical structures created among pay rates for different jobs in an organization including the way pay is distributed to employees, which in most organization is administered and allocated by immediate supervisor. Lastly, benefits is indirect pay to the individual in the form of payment for time not work, such as vacations, insurance, pensions, income maintenance, and miscellaneous services, which are set by organization and vary based on job classification of employees.

Some studies support that pay satisfaction is negatively related to and predictor of turnover and turnover intention. Motowidlo (1983) explored the relationships between amount of pay, pay satisfaction, and expectation with pay with withdrawal cognition, and actual quitting. Pay satisfaction was more potent determinant of withdrawal cognition than general satisfaction. Accordingly, the effects of pay on turnover were mediated by pay satisfaction and withdrawal cognition. Currall, Towler, Judge, and Koln (2005) examined the linkage between 
pay satisfaction and performance outcomes at the organizational level. With respect to the four dimensions of pay satisfaction, they found that turnover intention was negatively related to those dimensions. Williams, McDaniel, and Nguyen (2006) conducted a meta-analysis study of the antecedents and consequences of pay level satisfaction and found that turnover and turnover intention were the consequences of pay level dissatisfaction.

Some other studies emphasizing the dimensionality of pay satisfaction also showed a support to the way pay satisfaction predict turnover intention. Singh and Loncar (2010) tried to find the relationship among pay satisfaction, job satisfaction, and turnover intention. They found that all dimensions of pay satisfaction were correlated negatively with turnover intention. Carraher (2011)'s study about the attitudes toward benefits and pay found that benefits, pay, and satisfaction was important in affecting turnover and useful to retain employees. Motshegwa (2011) also found that pay satisfaction was a predictor for turnover intention.

$>$ Hypothesis 1: All of the dimensions of pay satisfaction will be negatively correlated with the components of turnover intention.

\subsection{Turnover Intention and Affective Commitment}

According to Meyer and Allen (1991), organizational commitment is a feeling and/or beliefs concerning the employee's relationship with an organization. They proposed that organizational commitment has several components, which is called as the three-component model. Affective commitment reflects an emotional attachment to, identification with, and involvement in the organization. Normative commitment reflects a feeling of obligation to continue employment. Lastly, continuance commitment is an awareness of the cost associated with leaving organization. Organizational commitment reflects the employee's relationship with the organization and has implications for the decision to continue the membership in the organization. A person who is committed to the organization, is more likely to stay in the organization and has no intention to leave (Steers \& Porter, 1983; Meyer \& Allen, 1991).

Some studies have found commitment as the predictor of turnover intention. Porter, Steers, Mowday, and Boulian (1974) suggested that organizational commitment was clearly the most important variable in differentiating between the stayers and the leavers. Mueller and Price (1990) explained that voluntary turnover was influenced by economic, psychological, and social determinants. One of the variables mentioned as a factor affecting turnover and turnover intention was commitment. Perryer, Jordan, Firns, and Travaglione (2010) investigated the way commitment (affective and continuance) interacted with perceived organizational support in predicting turnover intention. They found that the three variables were negatively related to turnover intention, with affective commitment as the best predictor. A meta-analysis study conducted by Meyer, Stanley, Herscovitch, and Topolnytsky (2002) about the predictors and consequences of commitment also suggested that organizational commitment might negatively affect turnover intention.

It is interesting that regarding the concept of the three-component model of organizational commitment, affective commitment has been mostly found as the strongest predictor of turnover and turnover intention compared to the other components. Summing up the findings of previous studies, Meyer et al. (2002) showed that the highest correlation with turnover was Affective Commitment Scale $(\rho=-.19)$, compared to Normative Commitment Scale $(\rho=-.16)$, and Continuance Commitment Scale $(\rho=-.10)$. Even a higher number was found as the correlation of organizational commitment with turnover intention, with Affective Commitment Scale as the highest $(\rho=-.59)$, relative to Normative Commitment Scale $(\rho=-.39)$, and Continuance Commitment Scale $(\rho=-.17)$.

$>$ Hypothesis 2: Affective commitment will be negatively related to the components of turnover intention. 


\subsection{The Mediation Relationship of Pay Satisfaction, Affective Commitment, and Turnover Intention}

According to the dynamics of the turnover model, there are three sequential parts explaining turnover process. First, the employees always have expectations from the organization. If those expectations are met, they will be satisfied and have positive attitude, otherwise they will feel dissatisfaction. This dissatisfaction feeling will lead to the negative attitude toward the organization. Second, the affective responses to the job, such as satisfaction or dissatisfaction and commitment, will lead to the behavioral intention. In case of turnover, the affective responses such reduced feeling of satisfaction and commitment may lead to an intention to leave the organization. Third, if there are some available alternative jobs, the intention to leave the organization will be translated into the actual behavior, actual turnover. In short, it can be inferred that one thing which is really important and can yield a withdrawal behavior is dissatisfaction (Cascio, 1998; Steers \& Porter, 1983).

As the only tangible reward of the work done by the employee, pay is critical. The amount of pay that employees receive affects their decisions about whether to stay or to leave. How hard they work and the productivity from their efforts are determined by the way pay is administered (Cascio, 1998). Satisfaction with pay is clearly related to one type of work behavior, which is the willingness of individuals to continue as employees of an organization and to show up for work on regular basis. When people feel satisfied with their job, they will perceive it as an advantage to continue to be a member of the organization (Lawler, 1986).

Some studies found a positive relationship between pay satisfaction and affective commitment. Ward and Davis (1995)'s study examined the effect of benefit satisfaction on organizational commitment and found positive correlation of benefit satisfaction, distributive justice, procedural justice, and the three components of organizational commitment. Miceli and Mulvey (2000) examined the consequences of satisfaction with pay level and pay system. They found that both of pay level and pay system satisfaction was positively related to affective commitment with the employers. Meyer et al. (2002)'s meta-analysis study also found a positive correlation between pay satisfaction and the three components of organizational commitment. Islam et al. (2012) analyzed the employees' compensation impact on commitment and job satisfaction. They found that the compensation was positively correlated with job satisfaction and commitment.

$>$ Hypothesis 3: Pay satisfaction will be positively correlated with affective commitment.

A meta-analysis study conducted by Griffeth et al. (2000) investigated some factors such as personal characteristics, satisfaction, other dimensions of work experience, external environment factors, behavior predictors, cognition and behaviors of withdrawal process, as the antecedents of turnover. Based on their findings, turnover was predicted more strongly by commitment than compensation (i.e., pay, pay satisfaction, and distributive justice). As it suggested commitment as a stronger predictor of turnover than pay satisfaction, there was a probability of mediation relationship among the variables.

There were a few studies conducted to test the mediation relationship involving pay satisfaction, commitment, and turnover intention. Lum et al. (1998) conducted a study investigating nursing turnover and examining the mediation relationship of pay satisfaction, job satisfaction, commitment, and turnover intention. They found that turnover intention was directly predicted by commitment and indirectly predicted by job satisfaction. Pay satisfaction had direct and indirect effects on turnover intention via job satisfaction and commitment.

Another study testing a mediation relationship conducted by Vandenberghe and Tremblay (2008) which focused more on the effects of pay satisfaction on commitment and turnover intention. Using two samples of subjects, they emphasized the multidimensionality of pay satisfaction (i.e., pay level, raise, structure and administration, and benefits) and organizational commitment constructs (i.e., affective commitment, normative commitment, perceived sacrifice, and perceived lack of alternatives). They found that pay satisfaction could directly and indirectly affect turnover intention. Although all of the components of commitment showed negative correlation with turnover intention, only affective commitment and perceived sacrifice which were found to fully 
A'yuninnisa, R. N, \& Saptoto, R.

mediate the relationship of pay satisfaction and turnover intention.

Hypothesis 4: There will be both direct and indirect effects of pay satisfaction on turnover intention, which is mediated by affective commitment.

\section{Method}

\subsection{Subject}

Subjects of this study were employees of an automotive manufacture company in Indonesia, who had been hired for at least 3 months. The data were collected from four offices of this automotive company to make sure that there were some representations from every office. In total, 183 questionnaires were distributed and 163 questionnaires were returned. Finally, 13 questionnaires were not included in analysis due to incomplete filling. One hundred and fifty subjects involved in this study were 115 (76.7\%) men and $35(23.3 \%)$ women, from the four offices. The respondents' age were ranging from 21 to $52,(M=28.5 ; S D=6.41)$. Hence, the respondents' tenures were ranging from 3 until 196 months, $(M=38.18 ; S D=44.11)$. Based on their level, $98(65.3 \%)$ respondents were staff, $26(17.3 \%)$ respondents were supervisors, 11 (7.3\%) respondents were assistant managers, and $15(10 \%)$ respondents were managers.

\subsection{Instruments}

The data were collected using three scales: Turnover Intention Scale, which was constructed by the authors, the Indonesian version of Pay Satisfaction Questionnaires and Affective Commitment Scale. After receiving professional judgments to keep the internal validity, all of the scales were field-tested before being used for the main data collection. The data from the field testing were used to eliminate some items which were not qualified to be used and potential to lower the reliability and validity of the scales.

Turnover Intention Scale - This scale was constructed to know the level of turnover intention among employees. It was developed using two components of turnover intention (Mobley et al., 1979), namely intention to leave and intention to search. Each of components was constructed using the aspects of intention by Ajzen (1991), namely attitude, subjective norm, and perceived behavioral control. Totally, there were 30 items on 5-point scales, ranging from "True of Myself" to "Not at All True of Myself". However, 7 items were not used for the data collection as it lowered the internal consistency of the scale. At last, the scale consisted of 23 items used further. Since this scale has two components of intention to turnover, there were two total scores for Intention to Leave and Intention to Search, which were derived by summing up the items of each component. The two components of turnover intention were then called as observed variables which were considered in estimating a latent variable called turnover intention used in the later analysis.

The Alpha coefficients of the scale were .84 for Intention to Leave and .91 for Intention to Leave. Using the reliability computation for a multidimensional scale, the overall stratified alpha coefficient was .94 for Turnover Intention Scale.

Pay Satisfaction Scale - The scale used to measure pay satisfaction in this study was the Indonesian-translated version of Pay Satisfaction Questionnaire (PSQ) constructed by Heneman and Schwab (1985). The original version of PSQ was translated into Bahasa Indonesia and translated back to English before being used. This scale aims to measure pay satisfaction and consists of four dimensions, namely: Pay Level, Pay Raise, Pay Structure/Administration, and Benefits. The scale consisted of 18 items, in which each item represents statement to which the subject responded on 5-point Likert-type scales, ranging from "Very Not Satisfied" to "Very satisfied". Since this scale has four dimensions, it results four scores of the dimensions. These four observed variables result a latent variable, called pay satisfaction which was used later for the analysis. 
The Alpha coefficients of the scale were satisfactory: .86 for Pay Level, .81 for Pay Raise, .81 for Structure/Administration, and .83 for Benefits. Using the internal consistency computation for a multidimensional scale, overall the stratified Alpha coefficient was .94 for Pay Satisfaction Questionnaire. Thus, it suggested that the scale has good reliability.

Affective Commitment Scale - The scale used to measure organizational commitment is the Indonesian-translated version of Three-Component Model (TCM) (Allen \& Meyer, 1990), particularly Affective Commitment Scale (ACS). This scale was translated into Bahasa Indonesia and back-translated into English before being used. This scale measures affective commitment component which reflects an emotional attachment to, identification with, and involvement in the organization. There were totally 9 items in this scale. However, two items were removed as they lowered the internal consistency of the scale. Finally, the scale used for the data collection consisted of 7 items. All items represent statements to which the subject responds on 5-point scales, ranging from "Mostly True of Myself" to "Not at All True of Myself". The total score was derived by summing up the score of each statement, which was used to see the correlation among the scales of the questionnaires. However, as the analysis was conducted using path analysis with latent variables, the overall score was not used. Each of the items then becomes observed variable to be calculated to form a latent variable called affective commitment. Overall, the Alpha coefficient of the scale was .76.

\subsection{Analysis}

This study conducted correlation analyses to examine the relationship among dimensions of Pay Satisfaction, Affective Commitment Scale, and components of Turnover Intention in testing hypothesis 1, 2, and 3. This correlation analyses were also used to make sure that all of the variables included were satisfactory related before the path analysis was conducted. Pearson correlation analyses were conducted to test the hypotheses using IBM SPSS 21.

Hypothesis 4 aimed to see the mediation relationship among pay satisfaction, affective commitment, and turnover intention. In doing so, this study used path analysis with latent variables. In this study, path analysis aims to examine the direct and indirect effect of pay satisfaction on turnover intention or to examine the mediating effect of a variable in a relationship of an independent and a dependent variable (Howitt \& Cramer, 2011). The three latent variables formed were pay satisfaction, affective commitment, and turnover intention. Pay Satisfaction was formed as the latent variable for observed variables namely pay raise, level, structure/ administration, and benefits. Affective Commitment comprised the seven scores of the Affective Commitment Scale. Lastly, Turnover Intention was the latent variable for intention to search and intention to leave. The analysis was conducted using LISREL 8.80 Student (Jöreskog et al., 2001).

There were several steps conducted to examine the direct and indirect effects of pay satisfaction on turnover intention. Firstly, the indirect and direct effects (i.e.,, partial mediation) were tested by including all variables: pay satisfaction, affective commitment, and turnover intention. Finally, to see the possibility of full mediation relationship, the indirect effect of pay satisfaction was tested by freeing the path from pay satisfaction to turnover intention. The fit of the model was assessed in terms of the four indices of the Normal Theory Weighted Least Squares Chi-Square $\left(\chi^{2}\right)$, Root Mean Square Error of Approximation (RMSEA), the Non-Normed Fit Index (NNFI), and the Comparative Fix Index (CFI). The model fit is represented by non-significant Chi-Square, RMSEA $<.080$, NNFI $\geq .95$, and CFI $\geq .95$ (Hooper, Coughlan, \& Mullen, 2008).

\section{Results}

Table 1 presents the descriptive statistics and correlations among all of the variables involved in this study. As can be seen, all of the variables involved beyond the demographic variables show significant relationships. Hypothesis 1, which proposed that there would be negative correlations between all dimensions of pay satisfaction and components of turnover intention, was supported. pay level, raise, structure/administration, and 
benefits are negatively correlated to intention to search and intention to leave, with the correlations ranging from -.18 to -.42 . Pay level shows the highest number of correlation with both intention to search $(r=-.42, p \leq .01)$ and intention to leave $(r=-.29, p \leq .01)$, relative to other dimensions of pay satisfaction. Intention to search also shows relatively higher numbers of correlation with the dimensions of pay satisfaction (ranging from -.30 to -.42, $p \leq .01$ ), compared to intention to leave (ranging from -.18 to $-.29, p \leq .05$ ).

Hypothesis 2, which proposed that there would be negative correlations between affective commitment and components of turnover intention, was confirmed. Affective commitment shows a moderate to high negative correlation with both intention to search $(r=-.66, p \leq .01)$ and intention to leave $(r=-.65, p \leq .01)$. Hypothesis 3 , which proposed that there would be positive relationship between all dimensions of pay satisfaction and affective commitment, was also supported. The highest number of correlation of affective commitment is found with pay level and benefits $(r=.26, p \leq .01)$, while the relationship with pay structure/administration is the lowest one ( $r$ $=.18, p \leq .05)$.

Regarding the relationships of the dimensions of pay satisfaction and affective commitment with intention to search and intention to leave, a comparison can be made to see the possibility of a more direct predictor of turnover intention. As can be seen, affective commitment shows a higher number of correlation with intention to search $(r=-.66, p \leq .01)$ and intention to leave $(r=-.65, p \leq .01)$, compared to all dimensions of pay satisfaction which show correlation ranging from -.18 to -.42 . Thus, it could be assumed that affective commitment is the more direct predictor of turnover intention, which was tested in the later analysis.

\section{Table 1}

Descriptive statistics and correlations for the study variables

\begin{tabular}{|c|c|c|c|c|c|c|c|c|c|c|c|}
\hline Variable & $M$ & $S D$ & 1 & 2 & 3 & 4 & 5 & 6 & 7 & 8 & 9 \\
\hline 1. Age & 28.50 & 6.41 & - & & & & & & & & \\
\hline 2. Tenure & 38.18 & 44.11 & $.72^{* *}$ & - & & & & & & & \\
\hline 3. Pay Level & 11.69 & 3.05 & -.02 & .80 & - & & & & & & \\
\hline 4. Pay Raise & 11.57 & 2.96 & -.05 & .50 & $.75^{* *}$ & - & & & & & \\
\hline 5. Pay Structure/Adm. & 16.79 & 3.92 & -.01 & .92 & $.70^{* *}$ & $.75^{* *}$ & - & & & & \\
\hline 6. Benefits & 12.29 & 2.89 & .01 & .90 & $.53^{* *}$ & $.60^{* *}$ & $.46^{* *}$ & - & & & \\
\hline 7. Affective commitment & 22.48 & 3.70 & $.31^{* *}$ & .00 & $.26^{* *}$ & $.23^{* *}$ & $.18^{*}$ & $.26^{* *}$ & - & & \\
\hline 8. Intention to Search & 42.41 & 8.36 & -.16 & .05 & $-.42^{* *}$ & $-.35^{* *}$ & $-.36^{* *}$ & $-.30^{* *}$ & $-.66^{* *}$ & - & \\
\hline 9. Intention to Leave & 30.89 & 5.70 & -.11 & .19 & $-.29^{* *}$ & $-.27^{* *}$ & $-.28^{* *}$ & $-.18^{*}$ & $-.65^{* *}$ & $.82^{* *}$ & - \\
\hline
\end{tabular}

The statistical fit of a model in which pay satisfaction affected turnover intention both directly and indirectly through affective commitment was tested using path analysis with latent variables using LISREL 8.80 Student. Each of the three latent variables was measured by the observed variables. With 62 degrees of freedom for this model chi-square was $109.86, p<.01$, RMSEA was .072, NNFI was .95, and CFI was .96. Although the value of Chi-Square was significant, the other indices suggested that the model was fit.

The effect of pay satisfaction on turnover intention was significant, $\gamma_{1}=-.19, p<.05$; each 1 score increase in pay satisfaction predicted approximately .56 decreasing of the turnover intention. Pay satisfaction was significantly predictive of the hypothesized mediating variable, affective commitment, $\gamma_{2}=.32, p<.05$. When controlling for pay satisfaction, commitment was significantly predictive of turnover intention, $\beta=-.77, p<.05$; each 1 score increase in affective commitment predicted approximately 9 decreasing of the turnover intention.

Examining a possible full mediation relationship, the model was tested by freeing the path from pay satisfaction to turnover intention. This new model yielded poor model fit and non-significant improvement in the model fit with $\lambda_{\text {diff }}^{2}=6.33$. As the path was not significant, it suggested that the partial mediation model was better to explain the effect of pay satisfaction on turnover intention. Thus, hypothesis 4 suggesting that there 
The effects of pay satisfaction and affective commitment on turnover intention

would be both the direct and indirect was confirmed. Figure 2 shows the model of hypothesis testing result.

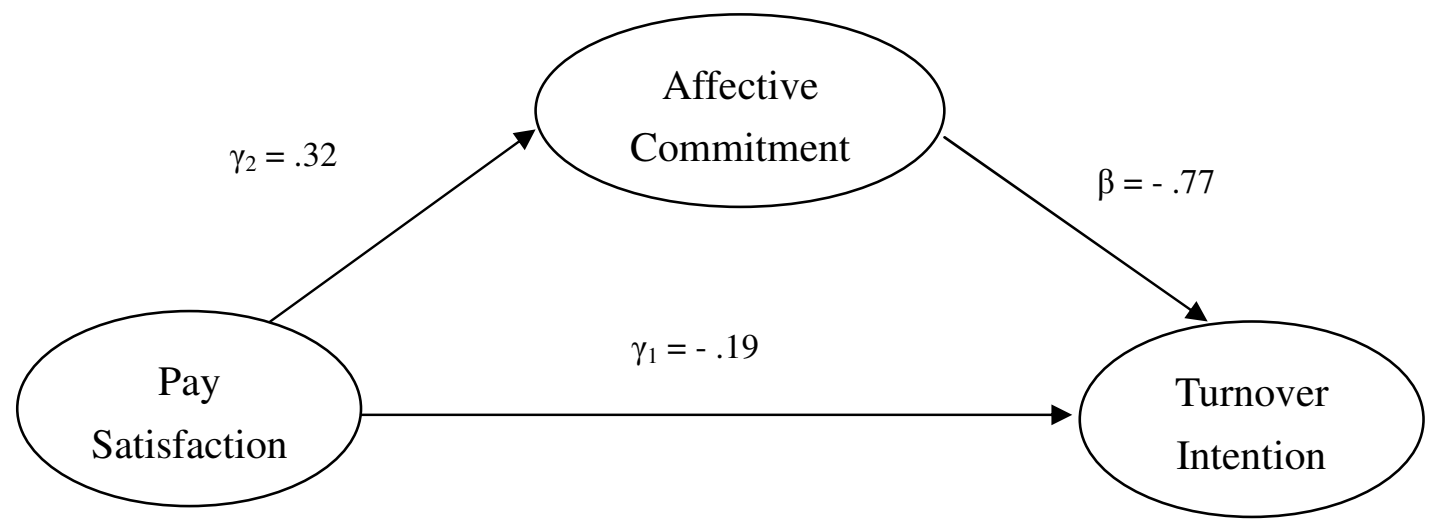

Figure 1. The direct and indirect effects of pay satisfaction on turnover intention

The result suggests that pay satisfaction may affect turnover intention both directly and indirectly via affective organizational commitment. Hence, the indirect effect proves the effectiveness of affective organizational commitment as a mediator in the relationship between pay satisfaction and turnover intention.

\section{Discussion}

This study aimed to test the mediation relationship among pay satisfaction, affective commitment, and turnover intention, such that pay satisfaction would have direct and indirect effects on turnover intention via affective commitment. Firstly, correlation analyses were conducted to see the relationship among the variables involved in this study. As pay satisfaction and turnover intention scales were multidimensional, the analyses were conducted with the observed variables representing each dimension of the scales. Then, path analysis was conducted to examine the path model of the meditation relationship.

The results showed that pay satisfaction's dimensions, affective commitment, and turnover intention's components were correlated to each other. Negative correlations were found between the dimensions of pay satisfaction and the components of turnover intention. This finding supports the previous studies suggesting that pay satisfaction and turnover intention was negatively related. This finding is in line with the previous studies suggesting the relationship of pay satisfaction and turnover intention (Currall et al., 2005; Motowidlo, 1983; Williams et al., 2006), as well as studies which emphasized the dimensions of pay satisfaction and their relations to turnover intention (Carraher, 2011; Motshegwa, 2011; Singh \& Loncar, 2010). If employees feel satisfied with their pay, they would be less likely to have an intention to leave and search for alternative jobs.

It was also found that among the dimensions of pay satisfaction, pay level was one dimension showing the higher correlation with intention to leave and intention to search, relative to the other dimensions. This result suggests that pay level is relative important in explaining turnover intention in the way employees want to leave the organization and search an alternative job. This finding confirms a meta-analysis study (Williams et al., 2006) emphasizing pay level satisfaction and its antecedent. In addition, pay level satisfaction was moderately and negatively correlated with turnover intention. It seemed that pay level satisfaction was more important than pay raise satisfaction in explaining pay satisfaction. Relative to intention to leave, intention to search was found to relate more with the dimensions of pay satisfaction. This indicated that employees who are satisfied with their pay are less likely to have an intention to search an alternative job then to quit.

Affective commitment was also negatively correlated to both intention to leave and intention to search. This finding gives a support to the previous studies (Meyer et al., 2002; Perryer et al., 2010). Commitment is an important variable in differentiating between the stayers and the leavers (Steers et al., 1974) or is perceived as the determinants of turnover (Mueller \& Price, 1990). In accordance to the assumption of Steers and Porter (1983), Meyer and Allen (1991), and Meyer et al. (2002), the highly committed employees are likely to stay in 
the organization, while the ones not committed are more likely to leave.

Affective commitment was also positively correlated with pay satisfaction which gave a support to the previous empirical and meta-analysis studies investigating the same variables (Islam et al., 2012; Meyer et al., 2002; Miceli \& Mulvey, 2000; Ward \& Davis, 1995). Affective commitment is influenced by employees' satisfaction with their pay. If they perceive that they receive compensation as they expect regarding also to the fairness, they will be more likely to continue their membership in the organization (Lawler, 1986).

The comparison of the way pay satisfaction and affective commitment correlated with turnover intention also were found in the result. It was found that the correlations of affective commitment and intention to leave and intention to search were moderate to high, which were higher than the correlations of all pay satisfaction' dimensions and turnover intention's components. This result gives a confirmation to the meta-analysis study of Griffeth et al. (2008) and Perryer et al. (2010) which found that affective commitment showed a higher correlation to turnover intention, compared with pay satisfaction. This indicates that there is a probability that affective commitment compared to pay satisfaction is the more direct predictor of turnover intention. This assumption was the tested in the later mediation analysis of the variables.

The result of hypothesis testing for the mediation relationship showed that, as it was assumed before, pay satisfaction may affect turnover intention directly and indirectly. The direct effect of pay satisfaction on turnover intention can be explained by the assumption that satisfaction is the determinant of voluntary turnover. Based on some perspectives explaining the way satisfaction effects turnover, pay is one thing which is crucial to be considered as the reason of leaving. Regarding the economical perspective, pay is one factor which is considered as a benefit and advantage from working exchange between the employer and employees. When the employees feel satisfied with it, they tend to stay working with the employer. Based on psychological perspective, pay is one thing which is expected by the employees. If their expectations are not met, they will feel dissatisfied which leads to turnover intention. Regarding the sociological perspective, pay functions as a reward system which is given by the employer. If this reward is not acceptable, the employees will be dissatisfied and consider quitting from the job. It is also believed that monetary reward can give a direct impact on turnover intention. Thus, pay satisfaction is an important thing which can affect attitude to turnover (Mueller \& Price, 1990).

The indirect effect of pay satisfaction on turnover intention was mediated by affective commitment. It suggests that turnover intention is influenced by pay satisfaction and affective organizational commitment. Firstly, it is associated and predicts organizational commitment. Then, organizational commitment can predicts and is negatively associated with turnover intention. This finding can be explained by the dynamics of turnover model, consisting of three sequential parts explaining turnover process. First, met expectation of the employee will determine their affective response towards their jobs. In this case, pay is considered as something expected by the employees. If what they expect from their pay is not met, they will have negative affective response resulting dissatisfaction. Second, this negative response could be prolonged and lower their commitment, as the affect they felt based on negative evaluation towards the organization. By then, a behavioral intention emerges. In this case, pay dissatisfaction will decrease the commitment and produce behavioral intention to turnover. Third, if there are some available alternatives, that behavioral intention to leave will be translated to actual behavior (i.e., actual turnover) (Steers \& Porter, 1983).

Overall, this study does not approve the finding of Motshegwa (2011)'s study suggesting that although turnover intention was predicted by pay satisfaction, it was not significantly predicted by commitment. Vice versa, this study shows that turnover intention can be predicted by both pay satisfaction and organizational commitment. The result shows that affective organizational commitment plays role as a mediator in that relationship effectively. Although the full mediation was tested, it showed non-significant path and poor model. In other words, it suggests a partial mediation of affective organizational commitment on turnover intention is better in explaining the relationship between pay satisfaction and turnover intention. On one hand, this finding do not give support to the previous study by Vandenberghe and Tremblay (2008) which suggested that there was 
The effects of pay satisfaction and affective commitment on turnover intention

a full mediation relationship of pay satisfaction, affective commitment, and turnover intention. However, on the other hand, the results that there are both direct and indirect effects of pay satisfaction on turnover intention confirm their finding.

The result of this study gives either theoretical or practical contributions. Theoretically, this study gives a confirmation of the previous findings that there is a direct effect of pay satisfaction on turnover intention and indirect effect which is mediated by commitment. Specifically, this study emphasizes the importance of affective commitment in determining employees' intention to turnover. It also gives a contribution to a theoretical development in the topic of turnover, commitment, and pay satisfaction particularly in Indonesia.

Regarding the practicality, this finding can be implemented in the practical problem such that to reduce turnover intention, organization can enhance the employees' level of affective organizational commitment. It can be done by enhancing their positive affect in the organization, in term of doing their job or experiencing positive and supportive climate at work. The work can be designed to be fun and exciting as well as the environment and relationship among the employees which may result positivity (Judge \& Ilies, 2004). In addition, organization should also give more attention to the way compensation is distributed. The pay policy should be evaluated regularly by making sure that the pay level is appropriate with the job, the raise is properly done, and the distribution is fair. It does not only involve the monetary one, but also the benefits distribution. A good pay system and pay satisfaction will not only reduce an intention to quit, but it can also enhance employees' satisfaction, motivation, and performance (Carraher, 2011; Currall et al., 2005; Ghazanfar, Chuanmin, Khan, \& Bashir, 2011; Islam et al., 2012; Judge et al., 2010; Lai, 2011; Miceli \& Mulvey, 2000; Singh \& Loncar, 2010; Stringer, Didham, \& Theivananthampillai, 2011).

This study also has some weaknesses. This study was initially developed to be case-based, as it was done at a company which had a turnover case. Based on this reason, from the theoretical perspective, this study is minor. First, the variable used in this study was adjusted with the problem existed in the company. As the consequence, this study did not explore other possible variables that could give more prediction to turnover. Thus, it might not contribute much to the development of the research on this topic. Second, this study was done in a company with limited subjects of study. Therefore, the finding of this study cannot be generalized to the other companies or other context of occurrence. The other companies may have different characteristics, of its people and its system, and may have different cases. Thus, for the next studies investigating the same thing, it is suggested to involve some companies which are representatives to be able to make a generalization.

Finally, although this study give a new contribution about the way the pay satisfaction, commitment, and turnover intention are related as psychological state of employees in Indonesia, this study did not consider the cultural background of the respondents. There was no data about cultural background which could be taken into account in analysis. By this reason, the result cannot really represent Indonesians' psychological dynamic for that three variables. Thus, for the next studies conducted in Indonesia with the similar aim as this study, it is recommended to consider cultural background.

\section{Conclusion}

This study found the direct and indirect effects of pay satisfaction on turnover intention, which was mediated by affective commitment. The mediation relationship suggests that turnover intention can be decreased by increasing the level of pay satisfaction. However, it will be more meaningful to decrease turnover intention by increasing the level of affective commitment. Turnover intention, which consists of intention to leave and intention to search, is influenced by both pay satisfaction and affective organizational commitment. If employees feel dissatisfied with their pay, they will feel negative emotion and can affect their decision to stay in the organization or not. Once they have an intention to leave, they will also look for an alternative job. This turnover intention can be executed at a certain time. However, another possibility can also happen that although they experience dissatisfaction but they are highly committed to organization, their intention to quit can be buffered. 
Acknowledgements: The publication of this manuscript is funded by Indonesia Endowment Fund for Education (LPDP).

\section{Reference}

Ajzen, I. (1991). The theory of planned behavior. Organizational Behavior and Human Decision Process, 50, 179-211. http://dx.doi.org/10.1016/0749-5978(91)90020-T

Allen, N. J., \& Meyer, J. P. (1990). The measurement and antecedents of affective, continuance and normative commitment to the organization. Journal of Occupational Psychology, 63, 1-18. http://dx.doi.org/10.1111/j.2044-8325.1990.tb00506.x

Motshegwa, B. (2011). Comparative analysis of teachers' perception of equity, pay satisfaction, affective commitment and intention to turnover in Botswana. Journal of Management Research, 3(1), 1-21.

Carraher, S. M. (2011). Turnover prediction using attitudes towards benefits, pay, and pay satisfaction among employees and entrepreneurs in Estonia, Latvia, and Lithuania. Baltic Journal of Management, 6(1), 25-52. http://dx.doi.org/10.1108/17465261111100905

Cascio, W. F. (1998). Managing human resources: Productivity, quality of work life, profits. New York: McGraw-Hill.

Cho, Y. J., \& Lewis, G. B. (2012). Turnover intention and turnover behavior: Implications for retaining federal employees. Review of Public Personnel Administration, 32(1), 4-23. http://dx.doi.org/10.1177/0734371X11408701

Currall, S. C., Towler, A. J., Judge, T. A., \& Kohn, L. (2005). Pay satisfaction and organizational outcomes. Personnel Psychology, 58, 613-640. http://dx.doi.org/10.1111/j.1744-6570.2005.00245.x

Dolton, P., \& Newson, D. (2003). The relationship between teacher turnover and school performance. London Review of Education, 1(2), 132-140. http://dx.doi.org/10.1080/14748460306685

Dyer, L., \& Theriault, R. (1976). The determinants of pay satisfaction. Journal of Applied Psychology, 61(5), 596-604. http://dx.doi.org/10.1037/0021-9010.61.5.596

Ghazanfar, F., Chuanmin, S., Khan, M. M., \& Bashir, M. (2011). A study of relationship between satisfaction with compensation and work motivation. International Journal of Business and Social Science, 2(1), 120-131.

Griffeth, R. W., Hom, P. W., \& Gaertner, S. (2000). A meta-analysis of antecedents and correlates of employee turnover: Update, moderator test, and research implications for the next millennium. Journal of Management, 26(3), 463-488. http://dx.doi.org/10.1177/014920630002600305

Heneman, H. G. III., \& Schwab, D. (1985). Pay satisfaction: Its multidimensional nature and measurement. International Journal of Psychology, 20, 129-141. http://dx.doi.org/10.1080/00207598508247727

Hooper, D., Coughlan, J., \& Mullen, M. (2008). Structural equation modeling: Guidelines for determining model fit. Electronic Journal of Business Research Methods, 6(1), 53-60.

Howitt, D., \& Cramer, D. (2011a). Introduction to SPSS statistics in psychology: For version 19 and earlier (5th ed.). Essex: Pearson Education Limited.

Islam, T., Ahmad, Z., Ahmed, I., Ahmad, A., Saeed, M., \& Muhammad, S. K. (2012). Does compensation and demographical variable influence on teachers' commitment and job satisfaction? A study of University of the Punjab, Pakistan. International Journal of Business and Management, 7(4), 35-44. http://dx.doi.org/10.5539/ijbm.v7n4p35

Jöreskog, K. G., So“rbom, D, Du Toit, S., \& Du Toit, M. (2001). LISREL 8: New statistical features. Chicago, IL: Scientific Software International.

Judge, T. A., \& Ilies, R .(2004). Is positiveness on organizations always desirable? Academy of Management Executive, 18(4), 151-155. http://dx.doi.org/10.5465/AME.2004.15268761

Judge, T. A., Piccolo, R. F., Podsakoff, N. P., Shaw, J. C., \& Rich, B. L. (2010). The relationship between pay 
The effects of pay satisfaction and affective commitment on turnover intention

and job satisfaction: A meta-analysis of the literature. Journal of Vocational Behavior, 77, 157-167. http://dx.doi.org/10.1016/j.jvb.2010.04.002

Kreitner, R., \& Kinicki, A. (2010). Organizational behavior (9th ed.). New York: McGraw-Hill.

Lai, H. (2011). The influence of compensation system design on employee satisfaction. African Journal of Business Management, 5(26), 10718-10723.

Lawler, E. E. III. (1971). Pay and organizational effectiveness: A psychological view. New York: McGraw-Hill.

Lawler, E. E. III. (1986). High-involvement management. San Fransisco: Jossey-Bass Publisher.

Locke, E. A. (1969). What is job satisfaction? Organizational Behavior and Human Performance, 4, 309-336. http://dx.doi.org/10.1016/0030-5073(69)90013-0

Lum, L., Kervin, J., Clark, K., Reid, F., \& Sirola, W. (1998). Explaining nursing turnover intent: job satisfaction, pay satisfaction, or organizational commitment? Journal of Organizational Behavior, 19(3), 305-320. http://dx.doi.org/10.1002/(SICI)1099-1379(199805)19:3<305::AID-JOB843>3.0.CO;2-N

Meyer, J. P., \& Allen, N. J. (1991). A three-component conceptualization of organizational commitment. Human Resources Management Review, 1(1), 61-89. http://dx.doi.org/10.1016/1053-4822(91)90011-Z

Meyer, J. P., Stanley, D. J., Herscovitch, L., \& Topolnytsky, L. (2002). Affective, continuance, and normative commitment to the organization: A meta-analysis of antecedents, correlates, and consequences. Journal of Vocational Behavior, 61, 20-52. http://dx.doi.org/10.1006/jvbe.2001.1842

Miceli, M. P., \& Mulvey, P. W. (2000). Consequences of satisfaction with pay systems: Two field studies. Industrial Relations, 39(1), 62-86. http://dx.doi.org/10.1111/0019-8676.00153

Milkovich, G. T., \& Newman, J. M. (2005). Compensation. Singapore: McGraw-Hill.

Mobley, W. H., Griffeth, R. W., Hand, H. H., \& Meglino, B. M. (1979). Review and conceptual analysis of the employee turnover process. Psychological Bulletin, 86(3), 493-522. http://dx.doi.org/10.1037/0033-2909.86.3.493

Motowidlo, S. J. (1983). Predicting sales turnover from pay satisfaction and expectation. Journal of Applied Psychology, 68(3), 484-489. http://dx.doi.org/10.1037/0021-9010.68.3.484

Mueller, C. W., \& Price, J. L. (1990). Economic, psychological and sociological determinants of voluntary turnover. The Journal of Behavioral Economics, 19(3), 321-335. http://dx.doi.org/10.1016/0090-5720(90)90034-5

Park, T., \& Shaw, J. D. (2013). Turnover rates and organizational performance: A meta-analysis. Journal of Applied Psychology, 98(2), 268-309. http://dx.doi.org/10.1037/a0030723

Perryer, C., Jordan, C., Firns, I., \& Travaglione, A. (2010). Predicting turnover intentions: The interactive effects of organizational commitment and perceived organizational support. Management Research Review, 33(9), 911-923. http://dx.doi.org/10.1108/01409171011070323

Pinder, C. C. (2008). Work motivation in organizational behavior. New York: Psychology Press.

Podsakoff, N. P., LePine, J. A., \& LePine, M. A. (2007). Differential challenge stressor-hindrance relationship with job attitudes, turnover intention turnover and withdrawal behavior: A meta-analysis. Journal of Applied Psychology, 92(2), 438-454. http://dx.doi.org/10.1037/0021-9010.92.2.438

Porter, L. W., Steers, R. M., Mowday, R. T., \& Boulian, P. V. (1974). Organizational commitment, job satisfaction and turnover among psychiatric technicians. Journal of Applied Psychology, 59(5), 603-609. http://dx.doi.org/10.1037/h0037335

Price, J. L. (1979). A theory of turnover. In B. O. Pettman (Ed.), Labour turnover and retention (pp. 51-75). Hampshire: Gower Press.

Scarpello, V., Huber, V., \& Vandenberg, R. J. (1988). Compensation satisfaction: Its measurement and dimensionality. Journal of Applied Psychology, 73(2), 163-171. http://dx.doi.org/10.1037/0021-9010.73.2.163

Shaw, J. S. (2011). Turnover rates and organizational performance: Review, critique, and research agenda. Organizational Psychology, 1(3), 187-213. http://dx.doi.org/10.1177/2041386610382152

Singh, P., \& Loncar, N. (2010). Pay satisfaction, job satisfaction, and turnover intent. Relations Industrielles, 65(3), 470-488. http://dx.doi.org/10.7202/044892ar

Steers, R. M., \& Porter, L. W. (1983). Motivation and work behavior (3rd ed.). New York: McGraw-Hill. 
A'yuninnisa, R. N, \& Saptoto, R.

Stringer, C., Didham, J., \& Theivananthampillai, P. (2011). Motivation, pay satisfaction, and job satisfaction of front-line employees. Qualitative Research in Accounting \& Management, 8(2), 161-179. http://dx.doi.org/10.1108/11766091111137564

Tett, R. P., \& Meyer, J. P. (1993). Job satisfaction, organizational commitment, turnover intention, and turnover: Path analyses based on meta-analytic findings. Personnel Psychology, 46, 259-293. http://dx.doi.org/10.1111/j.1744-6570.1993.tb00874.x

Vandenberghe, C., \& Tremblay, M. (2008). The role of pay satisfaction and organizational commitment in turnover intentions: A two-sample study. Journal of Business and Psychology, 22, 275-286. http://dx.doi.org/10.1007/s10869-008-9063-3

Ward, E. A., \& Davis, E. (1995). The effect of benefit satisfaction on organizational commitment. Compensation \& Benefits Management, 11(3), 35-40.

Williams, M. L., McDaniel, M. A., \& Nguyen, N. T. (2006). A meta-analysis of the antecedents and consequences of pay level satisfaction. Journal of Applied Psychology, 91(2), 392-413. http://dx.doi.org/10.1037/0021-9010.91.2.392 